ARTIKKELI

\title{
KANSALLISET TIETEET, ETNOMUSIKOLOGIA JA LIIKKUVAN MAAILMAN PROBLEMATIIKKA
}

\author{
Tarja Rautiainen-Keskustalo
}

Suomalaisen etnomusikologian suhde perinnetieteisiin on ollut monella tapaa mielenkiintoinen: tieteenaloja on nivonut yhteen pyrkimys tarkastella perinteen asemaa ja merkityksiä yksilöiden ja yhteisöjen elämässä. Kuitenkin samalla musiikki abstraktina ja merkityksiä pakenevana ilmaisumuotona on ohjannut tieteenalaa toisaalle, erityisesti länsimaisen musiikkitieteen suuntaan. Erityisen leimaa-antavaa oppialalle onkin ollut länsimaisen taidemusiikin tutkimuksen haastaminen ja maailman musiikkikulttuureiden rikkauden ja moninaisuuden osoittaminen. 2010-luvulla tutkimusorientaatioiden välistä kamppailua ovat alkaneet syrjäyttää kentän ulkopuolelta tulevat paineet ja vaateet. Sitä mukaa kun länsimaisista yhteiskunnista on tullut mobiileja (Urry 2007; myös Urry 2002; 2003; Lehtonen 2013) eli liikkuvia niin ajatusten, arvojen kuin pääomienkin suhteen, liikkuvuudesta on tullut metafora, jonka avulla myös kulttuuria hahmotetaan. Kulttuuri näyttäytyy medioituneen arkielämän alati muuttuvana kontekstina, josta perinteiset arvoluokitukset (korkea-matala, arvokas-arvoton) eivät juuri saa otetta. Kulttuuri ei siis ole enää samalla tapaa henkisyyden ja yleisinhimillisten arvojen sfääri kuin vielä toisen maailmansodan jälkeen (Lehtonen 2014a, 28).

Uudessa tilanteessa etnomusikologia on joutunut puolustusasemiin akateemisessa maailmassa. Muutos on konkretisoinut erityisen hyvin etnomusikologian opetuksen osalta Tampereen yliopistossa. Tampereen yliopistossa annettavaa etnomusikologian opetusta pidettiin pitkään suomalaisen tutkijayhteisön piirissä erityisenä, sillä vain Tampereella etnomusikologiaa voitiin opiskella pääaineena - myöskään muissa Pohjoismaissa tätä mahdollisuutta ei ollut. 2000-luvulle tultaessa erontekoa oli jo vaikeampi tehdä, koska monet tutkimuskentän jakautumista edesauttaneet arvoasetelmat olivat liudentuneet, ennen kaikkea eronteko korkean ja matalan kulttuurin välillä. Tämän seurauksena musiikkitieteen opintosuunnitelmat alkoivat sisällöllisesti laajentua koko maassa. Tampereella kansaperinteen laitos ei nimenä enää vastannut kaikilta osin tutkimuksen ja opetuksen sisältöjä ja laitoksen nimi muutettiin musiikintutkimuksen laitokseksi vuonna 2001. Suurimman haasteen oppiaine kohtasi kuitenkin 2010, jolloin yliopistouudistus romutti valtion suojissa olleen autonomisen yliopistolaitoksen ja oppiaineet asetettiin kilpailemaan toistensa kanssa. Tampereen yliopistossa oppiainepohjaisesta opetuksesta siirryttiin laaja-alaisiin tutkinto-ohjelmiin, joissa laajaa substanssiopetusta ei ollut enää mahdollista antaa, vaan opetusta ryhdyttiin suunnittelemaan sellaisten teemojen varaan, jotka parhaiten sopivat tutkinto-ohjelman luonteeseen. 
Olin muutoksen silminnäkijä ja osin sen toimeenpanija. Itsenäinen laitos lakkautettiin ja oppiaine tuli osaksi laaja-alaista tutkinto-ohjelmaa. Uudessa ympäristössä myös oppiaineen nimi alkoi muodostua imagon kannalta ongelmaksi, koska esimerkiksi yliopistoon pyrkijät eivät jostain syystä hahmottaneet että kysymyksessä on musiikkiin liittyvä oppiaine. Etno-etuliite koettiin vieraana. Nimi muutettiinkin musiikintutkimukseksi, koska se yleisempänä käsitteenä nähtiin houkuttelevampana ympäristössä, jossa kilpailtiin näkyvyydestä, opiskelijoista ja resursseista.

\section{TUTKIMUSKYSYMYKSET JA AINEISTO}

Edellä kuvatut muutokset johtivat minut pohtimaan etnomusikologian oppihistoriaa: millaisena oppiaineen paikka länsimaisen taidemusiikin tutkimuksen ja perinnetieteiden välimaastossa näyttäytyi uudessa tilanteessa? Ennen kaikkea muutos näytti nostavan esiin kysymyksen siitä, miten ja millaisessa yhteiskunnallisessa tilanteessa alun perin Yhdysvalloissa kehittynyt oppiala otettiin osaksi suomalaisen tieteen kenttää 1960-luvulla. Prosessia, jossa kansainvälisiä virtauksia ei vain omaksuta, vaan niitä muovataan toimijoiden omien pyrkimysten ja paikallisten erityisolojen ohjaamina, on kutsuttu kotouttamiseksi (Alasuutari \& Qadir 2014). Seuraavassa tarkastelenkin sitä, miltä etnomusikologian kotouttamisprosessi, jonka alkujuuret palautan tässä artikkelissa 1960-luvun puoliväliin, näyttäytyy 2010 tapahtuneen yliopistouudistuksen ja uudistusta ympäröivien yhteiskunnallisten muutosten jälkeen. Erityisesti tarkastelen etnomusikologian suhdetta perinnetieteisiin, koska tämä suhde on kotouttamisprosessin ymmärtämisen kannalta keskeinen.

Etnomusikologian oppihistoriaa ei ole aiemmin tarkemmin pohdittu kotouttamisen näkökulmasta, vaikka sinällään etnomusikologian oppihistoriasta Suomessa on kirjoitettu suhteellisen paljon. Tällöin pääpaino on ollut oppialan sisäisten kehityslinjojen tarkastelussa (esim. Järviluoma 2001; Koiranen ym. 2003). Esimerkiksi Helmi Järviluoma (2001) tarkastelee sitä, kuinka 1960-luvun lopussa ja 1970-luvun alussa Erkki Ala-Könni pyrki toiminnallaan oikeuttamaan uuden oppiaineen perustamista Tampereen yliopistoon. Sinällään tässäkin prosessissa oli kyse kotouttamisesta, vaikka Järviluoma ei artikkelissaan nosta tätä tulkintaa esille. Kotouttamisen tarkastelu luo laajan perspektiivin ajan suomalaiseen yhteiskuntaan ja sitä leimanneisiin teemoihin. Yksi keskeinen teema on 1960-luvun nopea yhteiskunnallinen rakennemuutos, jolloin tapahtui Pauli Kettusen $(2008,89)$ mukaan "tietoinen irtiotto aiempaan eheään kansan ideaaliin". Tämän seurauksena "kansallista katsetta" (Beck 1999), eli ajatusta yhtenäisestä kansakunnasta itsestään selvänä toiminnan lähtökohtana, jouduttiin arvioimaan uudelleen ennen kaikkea niin, että yhteiskunnalliset ristiriidat tunnistettiin. Tämä uudelleenarviointi oli monella tapaa läsnä etnomusikologian kotouttamisprosessissa. Yhtäältä se leimasi etnomusikologian suhdetta perinnetieteisiin, jotka olivat myös uudessa tilanteessa joutuessaan reflektoimaan kansallista katsettaan (Häggman 2015, 173-178). Toisaalta kaupungistuminen, elämäntavan muutos ja populaarikulttuurin uudet muodot suuntasi uutta oppialaa yhteiskuntatieteiden suuntaan. 
Artikkelissa käytetty tutkimusaineisto liittyy Erkki Ala-Könnin (1911-1996) elämäntyöhön Tampereella ja erityisesti siihen, miten hänen myötävaikutuksellaan Tampereen yliopistoon perustettiin vuonna 1974 oppiaine nimeltään Kansanperinne, erityisesti kansanmusiikki, jonka piirissä etnomusikologista opetusta ja tutkimusta harjoitettiin. Aineisto koostuu erilaisista aikalaisdokumenteista, joista keskeisin on Suomalaisen Kirjallisuuden Seuran (SKS) vuonna 1965 julkaisema Kansallisten tieteiden kehittämisohjelma (KTK 1965). Näkemykseni mukaan se oli keskeinen Ala-Könnin toiminnan motiiveja selittävä tekijä. Muu primääriaineisto koostuu Ala-Könnin laajasta haastattelusta vuodelta 1981 (Kper Y08720) sekä erilaisista oppiaineen perustamiseen liittyvistä asiakirjoista ja lehtileikkeistä, joka ovat peräisin opetusministeriön arkistosta, Tampereen yliopiston arkistosta ja ainejärjestö Nefan arkistosta. Sekundaariaineistona olen käyttänyt väitöskirjani (Rautiainen 2001) lehtiaineistoa, joka koskee populaari- ja kansanmusiikin arvostuksesta käytyä keskustelua 1960-luvulla.

\section{KANSANKULTTUURI KARTALLE}

Yhdysvalloissa antropologian liepeillä toisen maailmansodan jälkeen syntyneen etnomusikologia-oppialan perustana on pidetty yleishumanistista ja -antropologista lähestymistapaa, jossa musiikkia on tarkasteltu inhimillisen toiminnan yhtenä aspektina. Kuitenkin kokonaisuudessaan oppialan historia on monitulkintaisempi. Suomalaiset tutkijat (Kurkela ym. 2003, 54-56) liittävät osaksi etnomusikologista traditiota myös eurooppalaisen musiikkitieteen piirissä syntyneen vertailevan musiikkitieteen, joka keskittyi kansanmusiikin tutkimukseen. Tämä on tuonut painotuseroja tutkimusalan luonteen ymmärtämiseen. Etnomusikologian käsitteellä on voitu viitata sekä ihmisen musiikillisen toiminnan kuvaamiseen ja selittämiseen ilman historiallista aspektia että historiatutkimukseen tai pitkälle vietyyn musiikkianalyysiin. Toisaalta oppialan yhteydet kulloisenkin ajankohdan poliittisiin virtauksiin ovat olleet kiinteä osa tieteenalan oppihistoriaa. Esimerkiksi kansallismielisillä liikkeillä oli vaikutuksensa vertailevan musiikintutkimuksen syntyyn ja kehitykseen. Niin ikään toisen maailmansodan jälkeinen nopea yhteiskunnallinen muutos muokkasi oppiaineen luonnetta. Monien etnomusikologien kiinnostus kohdistui 1950ja 1960-luvuilla siihen, mikä oli katoamassa - tai minkä ainakin koettiin olevan katoamassa. Yhdysvalloissa tämä tapahtui lähinnä antropologisen tutkimusperinteen piirissä, mutta niissä Euroopan maissa, joissa ei ollut kolonialismin perintöä, kuten Suomessa, etnomusikologinen lähestymistapa sai vastakaikua perinnetieteiden piirissä. Yhteiskunnallisen muutoksen reflektoiminen ja menneisyyden nostalgisoiminen ovat olleet keskeinen osa myös perinnetieteiden itseymmärrystä. Seppo Knuuttila (1994, 9-14) kuvaa, kuinka kansankulttuurin tutkijoilla menneisyyden nostalgisoiminen on tullut esille menetetyn kultaisen ajan haikailemisena ja samalla on oltu huolissaan esimerkiksi autenttisuuden ja sosiaalisen eheyden sekä moraalisen varmuuden pirstoutumisesta. (Ks. myös Anttonen 2005, 104-I05.)

Varsinaisesti etnomusikologisen tutkimusperinteen alkuvaiheet Suomessa on paikannettu 1970-luvun alkuun, jolloin Helsingin musiikkitieteen oppiaineessa aloitettiin etnomusikologian opetus tuntiopetuksena (Koiranen ym. 2003; Kytö \& Rantanen 2014 , 9). Tämä on siinä mielessä oikea tulkinta, että käsitettä etnomusikologia ryhdyttiin tuolloin systemaattisesti käyttämään. Kuitenkin väitän, että maaperä 
etnomusikologian kotouttamiselle luotiin jo aiemmin, 1960-luvun puolivälin aikoihin. Tuolloin näyttää syntyneen yhteinen tulkintahorisontti kansatieteilijöiden, kielentutkijoiden ja kansanrunoudentutkijoiden sekä musiikintutkijoiden, erityisesti Erkki Ala-Könnin, välillä. Yhteistä intressiä taustoitti nostalginen katse menneisyyteen. Tutkijoiden ja toimijoiden konkreettiset pyrkimykset olivat kuitenkin tulevaisuudessa: yhteiskunnallinen murros siivitti pyrkimyksiä suunnitella sitä, miten oppialat voisivat olla kehittämässä suomalaista yhteiskuntaa.

Vuonna 1965 Suomalaisen Kirjallisuuden Seura julkaisi Kansallisten tieteiden kehittämisohjelman 1966-80. Se perustui seuran aloitteesta koolle kutsutun toimikunnan työn tuloksiin. Toimikunnan puheenjohtaja oli Kustaa Vilkuna ja työryhmän työskentelyyn osallistui eri tavoin 41 asiantuntijaa, muun muassa Matti Kuusi, Lauri Honko, Ilmar Talve, Pertti Virtaranta, Lauri Viljanen ja Erkki Ala-Könni. Kehittämisohjelmasta ei selkeästi käy esille perimmäinen syy sen laatimiselle; saatesanoissa kuitenkin todetaan kuinka "suppeampi tieteenharjoittajien piiri oli huhtikuun lopulla kahdesti kokoontunut yksityiseen neuvotteluun kansallisten tieteiden ajankohtaisista organisaatio- ja kehittämiskysymyksistä" (KTK 1965, 5). Kai Häggmanin (2015, 165-170) mukaan ohjelman taustalla oli keskeisesti pyrkimys saada SKS:n toimintamenot osaksi valtion budjettia. Seuran saama valtionapu oli vuosien varrella pienentynyt ja johtokunta oli huolestunut siitä, että yhteiskunnan resursseja suunnattiin esimerkiksi koulutusuudistuksiin (peruskoulu, maakuntien uudet yliopistot), eikä perinteisiä tieteellisiä seuroja ei samassa mittakaavassa tuettu. Tässä tilanteessa julkisuuteen tuleminen ja alan merkityksen korostaminen oli tärkeää.

Kehittämistarpeita löytyi noin sadan sivun verran ja esitetty aikataulu oli nopea. Ohjelma julkaistiin jo samana vuonna, jotta se voitiin ottaa huomioon vuoden 1966 valtion tulo- ja menoarviota laadittaessa. Kielitieteillä on pääpaino esitetyissä hankkeissa ja Häggmanin $(2015,168)$ mukaan ohjelma olikin alkusysäys Kotimaisten kielten tutkimuskeskuksen perustamiseen. Muut hankkeet kohdistuivat kansanrunouden, kansatieteen ja kirjallisuuden tutkimukseen.

Häggman $(2015,169)$ pitää kehittämisohjelmaa viisikymmenlukulaisena, koska se sisälsi vain vähän uusia avauksia. Esimerkiksi ohjelmassa keskeisesti esille noussut kansatieteellinen kartoitustyö oli aloitettu jo ennen sotia. Perusteluista huokuu tarve oikeuttaa kansanperinteen tutkimus, mikä sinällään oli seuran toiminnan ytimessä. Esimerkiksi Häggmanin (2015) tutkimus osoittaa sen, kuinka merkittävä ideologinen toimija SKS oli ollut 1930-luvulta lähtien ja kuinka se oli pyrkinyt pitämään yllä käsitystä muinaisuudessa vallinneesta kansallisesta yhtenäisyydestä. Tässä mielessä kehittämisohjelma on hyvä esimerkki siitä, miten aiempien vuosikymmenen kansallisesta katseesta haluttiin perinnetieteiden piirissä pitää vielä kiinni 1960-luvulla.

Kansallisten tieteiden aseman parantamista, perinteen keräämistä ja tutkimista perusteltiin 60-lukulaisella retoriikalla (ks. Kettunen, 2008, 89), joka on tuttua tänäkin päivänä, eli vetoamalla kansainväliseen kilpailukykyyn: 
Tarja Rautiainen-Keskustalo: Kansalliset tieteet, etnomusikologia ja...

[http://www.elore.fi/arkisto/2_15/rautiainen-keskustalo.pdf]

Maat, jotka menestyksellisimmin ovat turvanneet kansainvälisen kilpailukykynsä, panevat kansalaiskasvatuksessaan oman kielen ja kulttuurin tuntemukselle paljon enemmän painoarvoa kuin Suomi. Yleinen toteamus on, että maan taloudellinen ja henkinen merkittävyys, sen kansainvälinen ominaispaino, suuresti riippuu kansan kulttuuritasosta, jonka luomisessa taas omat kansalliset tieteet esittävät huomattavaa osaa. (KTK 1965, 7.)

Toimikunnan asettamaa tehtävää voidaan tulkita pyrkimyksenä suhteuttaa toisiinsa modernia ja traditionaalista, kansallista ja kansainvälistä, eli rakentaa modernia kansallisvaltiollista yhteiskuntaa. Tätä prosessia Pauli Kettunen (2008) on kuvannut kirjassaan Globalisaatio ja kansallinen me. Hän toteaa (mts. 136), kuinka kansallisvaltiollistumista ovat määrittäneet tehokkuutta, sosiaalista kiinteyttä ja itsekurinalaista kansalaisuutta koskevat teemat. Niiden puitteissa modernia ja traditionaalista suhteutettiin toisiinsa siten että molemmille annettiin kahdet kasvot. Moderni oli sekä olevan rikkomista että järjestyksen tekemistä. Traditionaalinen puolestaan näyttäytyi "yhteisöllisyytenä, jonka moderni uhkaavasti hajotti, ja irrationaalisuutena, jonka tilalle moderni toi tehokkuutta ja edistystä."

Vaikka Kettunen viittaa yleisesti 1800-luvulta alkaneeseen kehitykseen, olivat nämä piirteet yhä hyvin tunnistettavissa 1960-luvun suomalaisessa yhteiskuntakeskustelussa. Siten ei ole yllättävää, että kansallisten tieteiden kehittämisohjelman keskeisten toimijoiden pyrkimysten taustalta on myös löydettävissä Kettusen kuvamaa modernin ja traditionaalin välistä vuoropuhelua. Työkenttänä oli kansallinen kulttuuri, jonka vaaliminen ja säilyttäminen oli yhteinen tehtävä. Tämä tehtävä muotoiltiin seuraavasti: "Se kulttuuripääoma, jonka suomalainen tapaa Suomesta, mutta ei muualta, osoittautuu yhä edelleen sekä kansallisen yhteenkuuluvuutemme että kansainvälisen arvonantomme perusedellytykseksi" (KTK 1965, 7).

Modernin uhka tuli näkyviin perusteluissa, joissa esimerkiksi murteiden sekä aineellisen ja henkisen kansanperinteen keräämisellä nähtiin olevan kiire, koska maailma ympärillä oli muuttumassa. Kuten olen aiemmin tässä artikkelissa tuonut esille, tämä näkökulma on ollut keskeinen perinnetieteille Suomessa. Muutoksen seurauksena koettiin olevan autenttisuuden ja yhteisöllisyyden katoaminen (ks. Knuuttila 1994; Anttonen 2005). Tämä pelko nousi hyvin keskeisesti esiin ohjelmasta. Käynnissä oleva yhteiskunnallinen muutos nähtiin uhkana sosiaaliselle - ja samalla kansalliselle - koheesiolle, jonka seurauksena oli jopa 'aivovienti', ellei asiaan puututtaisi: "Kiintymys yhteisarvoihin pidättää kyvykkäitä kansalaisia siirtymästä korkeamman elintason maihin ja luo pohjaa omavaraisille ja siksi kansainvälisestikin varteenotettaville kulttuurisaavutuksille" (KTK 1965, 7).

Kettusen $(2008,8)$ mukaan kansallista katsetta on Pohjoismaissa värittänyt se, että oma asema on nähty perifeeriseksi, joten mallia on haettu 'edistyneemmistä' maista. Toimikunnan jäsenillä tätä asennetta ei kuitenkaan ollut, vaan alkusanoissa todettiin, kuinka "pienen maan mahdollisuudet yltää kansainvälisesti merkittäviin aikaansaannoksiin ovat kielen, historian, kirjallisuuden, taiteiden, kansanperinteen, tapojen ja uskonnon tutkimuksessa olennaisesti paremmat kuin useilla muilla tieteenaloilla (KTK 1965, 8)." Itsetietoinen asenne kertoo jälleen SKS:n vahvasta historiallisesta asemasta, johon liittyi myös suursuomalaisuuden ideologista kannattelua (Häggman 2015, 28-34; myös Knuuttila 2008, 456-460). 
Modernin tehokkuutta ja edistystä, jonka toivottuna lopputuloksena oli kansainvälisen kilpailukyvyn lisääminen, toi toiminnan organisoiminen ja pitkän aikavälin suunnittelu - kuten ajankohdan luonteeseen yleisemminkin kuului (Alasuutari 1996, 108-109). Kehittämisohjelmassa esitetään toteutettavaksi lukuisia hankkeita perinteen säilyttämiseksi. Keskeistä oli erilaisten museoiden ja arkistojen ylläpito sekä uusien perustaminen ja esimerkiksi sanakirjojen, erikoiskirjastojen ja kortistojen laatiminen, mikä osoittaa että perinteen säilyttäminen tulkittiin ensi sijassa arkistoimiseksi ja tallentamiseksi. Sitä näkökohtaa, miten perinne säilyisi elävänä, ei tuoda selkeästi esille toimenpiteissä. Tämä piirre kuvaa perinnetieteiden keskeistä dilemmaa: kuinka määritellä traditio suhteessa moderniin? Pertti J. Anttonen (2005) kuvaa kirjassaan Tradition through Modernity sitä, kuinka traditio on usein ymmärretty modernissa ajattelussa, ja myös perinnetieteissä, kulttuuri-ilmiöiden sisäsyntyiseksi ominaisuudeksi, sen sijaan että se ymmärrettäisiin merkityksenantona, joka tuottaa katkoksia ja jatkuvuuksia tavassamme ymmärtää kulttuuria.

Kehitysohjelman käsitys traditiosta on korostetusti erillisyyttä alleviivaava; traditio on siinä ikään kuin säiliö, joka erotetaan selkeästi nykyhetkestä. Voidaan siis sanoa, että kehittämisohjelma sisälsi SKS:n ideologiset juonteet, käsityksen kunniakkaasta yhtenäisestä kansasta, mutta ennen kaikkea pidän ohjelmaa pyrkimyksenä laatia Suomen kansasta kaikkine yksityiskohtineen - esineineen, elämäntapoineen ja murteineen - topografia, joka tarvittiin modernisoituvan maailman kohtaamiseen. Tietyllä tavalla ohjelman voi nähdä myös vastauksena ajankohdan sosiologisesti virittyneeseen yhteiskuntatutkimukseen, mihin palaan tässä artikkelissa myöhemmin.

Kettunen $(2008,16)$ kutsuu metodologiseksi nationalismiksi tätä prosessia, jossa tavoitteena on synnyttää käsitys kansallisesta yhtenäisyydestä. Tällä hän tarkoittaa ideologiaa, jossa kansakuntaisuus - ajatus että on olemassa kansakunniksi jakautunutta toimijuutta - on kyseenalaistamaton ja itsestään selvästi oikeana pidetty periaate. Käsite metodologinen viittaa tässä siihen, että tarkkailija- ja toimijaperspektiiviä ei reflektoida. Tämä tulee erityisen hyvin esiin myös kehittämisohjelman sivulta: kysymys on selkeästä ohjelmajulistuksesta, jossa keräämisestä ja säilyttämisestä muodostuu itsestään selvä toiminnan muoto.

Edellä sanottu ei kuitenkaan tarkoita sitä, että kaikilla SKS:n piirissä toimineilla olisi ollut samanlainen tulkintahorisontti tradition ja modernin yhteensovittamisesta. Kai Häggman $(2015,125)$ nostaa esille sen, kuinka esimerkiksi Matti Kuusi näki SKS:n kehittämisessä tärkeänä sen, että seura avaisi toimintaa suurelle yleisölle ja herättäisi keskustelua "psykologian ja sosiologian merkityksestä kansallisille tieteille". Tämä ei kuitenkaan sopinut arvokkaan akateemisen seuran toimintatapoihin kovin luontevasti.

\section{Erkki Ala-Könni ja kansallinen katse}

Modernin ja traditionaalisen, kansallisen ja kansainvälisen yhteensovittaminen jatkui Erkki Ala-Könnin toiminnassa hänen siirryttyä hoitamaan Tampereen Yhteiskunnalliseen korkeakouluun perustettua Kansanperinteen arkistoa juuri samana vuonna kun kehittämisohjelma laadittiin. Ala-Könni oli taustaltaan musiikkitieteilijä, mutta 
hänellä oli erityinen kiinnostus kansakulttuuriin. Opiskeluaikoinaan hän työskenteli Kalevalaseuran sihteerinä, myöhemmin puheenjohtajana, ja hänen väitöskirjansa Die Polska-Tänze in Finnland (1956) perustui hänen itse keräämiinsä kenttä-äänitteisiin. (Kukkurainen 1983, 9.) Hän toimi myös SKS:n piirissä, kuten Kansallisten tieteiden kehittämisryhmän jäsenyys osoittaa. Ala-Könnin välit SKS:aan eivät kuitenkaan olleet erityisen hyvät, sillä hän ei jostain syytä voinut siirtää mittavaa opiskeluaikanaan keräämäänsä perinneaineistoa SKS:n suojiin. Ristiriidasta ei ole kirjallisia dokumentteja, mutta haastattelussa Ala-Könni (Kper Y08720, 05) toteaa, kuinka "Helsinki tuntui toivottomalta" ja "halusin lähteä perustamaan jotakin kokonaan uutta." Pesäerosta kertoo myös se, että Ala-Könni ei halunnut noudattaa SKS:n luettelointikäytäntöjä omassa aineistossaan, vaan kehitti oman aineiston luokittelutavan.

Tampereella historian professori Aulis J. Alanen innostui ajatuksesta siirtää perinneaineisto Tampereelle, oletettavasti siksi, että uudella korkeakoululla oli vielä menossa etsikkoaika profiilinsa suhteen. Resursseja arkiston ylläpitoon korkeakoululla ei kuitenkaan ollut, vaan arkiston rahoittajaksi tuli Tampereen kaupunki vaikutusvaltaisen kunnallispolitiikan vaikuttajan, Erkki 'Napoleon' Lindforsin, myötävaikutuksella (Kper Y08720, 04). On syytä olettaa, että Lindfors näki arkiston hyvänä lisänä kaupungin imagoon.

Kuten monissa yhteyksissä on tullut ilmi (Koiranen ym. 2003; Järviluoma 2001), tutkimisen ohella Ala-Könnin intohimo kohdistui perinteen keräämiseen ja tämä tehtävä korostui hänen toiminnassaan Tampereella. Hänen ensisijainen työkenttänsä oli murroksessa olevan maaseudun kulttuurin pelastaminen ja tässä mielessä hän toimi perinnetieteiden viitekehyksessä ja toimintaa motivoi epäilemättä nostalginen katse menneisyyteen (vrt. Knuuttila 1994). Kuitenkin hänen aktiivisuutensa perinteen tallentamisessa oli omaa luokkaansa. Sen lisäksi että hän keräsi esineistöä soittimista alkaen, hän myös talletti suullista perinnettä, lauluja, soittoa, valokuvasi ja kopioi vanhaa valokuva-aineistoa (Kukkurainen 1983,11). Näyttää siltä, että hän oli ottanut omakseen Kansallisten tieteiden kehittämisohjelman tavoitteen luoda topografia suomalaisesta (katovasta) maaseudusta.

Erityinen piirre Ala-Könnin toiminnassa oli kuitenkin se, että lukuisat perinteenkeruumatkat maakuntiin ja näihin liittyvä muu toiminta tekivät hänestä perinteenkerääjän ohella maaseudun yhteisöllisyyden puolestapuhujan, kulttuuritoiminnan henkiin herättäjän ja kulttuurivaikuttajan. Rooli sisälsi myös aimo annoksen portinvartijuutta. Hän innovoi ja tuomaroi lukuisia kansanmusiikkikilpailuja ja innosti pelimanneja säveltämään uusia kappaleita (Järviluoma \& Saloniemi 1988). Tässä mielessä Ala-Könnin toiminta asettui kansallisvaltion sosiaalista kiinteyttä koskeviin teemoihin. Tampereen yliopisto Kansaperinteen arkiston lukuisat lehtileikekirjat 1960-luvun lopusta ja 1970-luvun lopusta (Kper, Lehtileikekokoelma) osoittavatkin, kuinka Ala-Könni halusi korostaa perinteen keräämisen merkitystä paikallisille inmisille. Kun paikallislehdessä kysyttiin provosoivasti sitä, hyötyykö tavallinen veronmaksaja keruutyöstä ja sen tuloksista, Ala-Könnillä oli tähän vastaus valmiina: 
Tarja Rautiainen-Keskustalo: Kansalliset tieteet, etnomusikologia ja...

[http://www.elore.fi/arkisto/2_15/rautiainen-keskustalo.pdf]

Tieteen lisäksi hyötyy aineistosta mm. kulttuuritoiminta ja opetustoiminta. Mm. Uudenkaupungin kouluilla on mahdollisuus saada aineisto opetusmateriaaliksi. Ja sanon, että jos historian opettaja osaa ammattinsa ja pystyy opettamaan, niin pelkästään kuvamateriaali innostaa oppilaat tutustumaan oppituntien lisäksi Uudenkaupungin museoon ja kirjoitettuun historiaan. (P.H. 1970.)

Tämän perusteella voitaisiin väittää, että Ala-Könni pyrki suhtautumaan perinteeseen myös reflektiivisesti, eikä vain säiliöimään sitä. Mitä tämä viime kädessä tarkoitti, on asia erikseen. Lehtiartikkeleiden perusteella voi päätellä, että perinteen eläväksi tekeminen merkitsi ennen kaikkea kotiseutumuseoiden perustamista ja toivetta siitä, että materiaalia käytettäisiin esimerkiksi kouluissa. 2010-luvun perspektiivistä pyrkimys ei ehkä näyttäydy varsinaisesti perinteen elävöittämisenä, mutta 1960-luvun hyvinvointivaltion kulttuuripolitiikalle (ks. Rautiainen 2001, 293-297), joka perustui valtion aktiiviseen rooliin kulttuurinpalvelujen tuottajana, nämä pyrkimykset sopivat hyvin.

Ajoittain Ala-Könnin aktiivinen keräysinto näyttää jopa itsetarkoitukselliselta, haastatteluissa Ala-Könni saattoi tokaista haastateltavalle, joka mietti liian kauan kysyttyä asiaa, että "kai te nyt sentään jotain muistatte!" (Tikka, suullinen tiedonanto, 2013). Myös kerätyn aineiston määrää (haastatteluntunteja, haastateltavia) korostettiin lehdistössä. Järviluoma ja Saloniemi $(1988,33)$ toteavatkin, että matkat olivat ehkä tarkoituksellisestikin näytösluontoisia. 1960-70 -lukujen maaltamuuton kurimuksessa perinteen näyttävä keräys toi maaseudulle kaivattua itsetuntoa, kun paikallisille voitiin osoittaa kuinka paljon perinnettä kylästä löytyykään. Tässä kohtaa perinteen elävyys jäi helposti taka-alalle ja ajatus perinteestä säiliönä astui esille; kenttätyön päätöstä voitiin kuvata seuraavaan tapaan: "Peräseinäjoen entisyys on tutkittu - retkikunta lopettaa työnsä tänään" (Vesterinen 1969).

Tehokkuutta ja edistystä Ala-Könni lähti hakemaan tutkimuksen piiristä, ja tässä kohtaa käsite etnomusikologia nousee esiin. Tarttuminen uuteen, angloamerikkalaiseen tieteenperinteeseen johtunee osaltaan Ala-Könnin ristiriidoista kansatieteilijöiden ja kansanrunoudentutkijoiden kanssa. Haastattelussa (Kper Y08720, 12-13) hän mainitsee, että halusi luoda oppiaineen, joka poikkeaisi luonteeltaan muista Suomen perinnetieteiden opinahjoista siinä että se olisi "praktisempi" ja "kouluttaisi kulttuurijohtajia, kulttuurisihteereitä ja auttaisi lehdistöoppia lukeneita kulttuurin pariin".

Oppiaineen perustaminen on sinällään pitkä, värikäs ja monipolvinen prosessi, jota Helmi Järviluoma (2001) on kiinnostavasti tarkastellut artikkelissaan Kansanmusiikki oppituolille - rajankäyntityön historiaa 1965-1983. Seuraavassa referoin lyhyesti Järviluoman kuvaamaa prosessia ja nostan esille joitakin uusia lähteitä, joiden avulla on mahdollista pohtia yhtäältä etnomusikologian kotouttamista ja toisaalta sitä, kuinka oppiaineen syntyhistoriaan kuului myös metodologisen nationalismin piirteitä.

Musiikkiin liittyvä opetus alkoi Tampereen Yhteiskunnallisessa korkeakoulussa vuonna 1965, jolloin tuli mahdolliseksi suorittaa musiikkitieteen approbatur-arvosanoja. Tampereen yliopistoksi vuotta myöhemmin muutettuun instituutioon perustettiin vuonna 1970 musiikkitieteen laitos ja tuolloin Ala-Könnin ja hänen 
kollegoidensa, ennen kaikkea Matti Raution päämääräksi tuli laajentaa opetusta niin, että se "huomioisi musiikissa tapahtuneet muutokset ja ajankohtaiset musiikilliset ilmiöt" (Järviluoma 2001, 67). Tämän vuoksi ehdotettiin kahden linjan perustamista: musiikkitieteen ja populaarimusiikin. Esitys ei toteutunut, mutta kaksi vuotta myöhemmin esitys uusittiin ja järjestys oli tällä kertaa päinvastainen, ensimmäiseksi esitettiin populaarimusiikin ja sivulinjaksi klassisen musiikin linjaa. Tällä monialaisuudella Ala-Könni (Kper Y08720, 13) sanoi halunneensa tavoitella juuri "praktisuutta" ja oppiaineen laajaa sovellettavuutta.

Musiikkitieteen opetuksen profiiliksi kaavailtiin keskittymistä nykymusiikin ja näyttämömusiikin alueelle, mutta populaarimusiikin kenttä oli visioissa avoimempi. AlaKönni halusi ymmärtää käsitteen laajasti ja määritti populaarin tarkoittavan kansan ja kansanelämän tutkimista. Ala-Könnin mukaan tämä tarkoitti kaiken taidemusiikin ulkopuolella olevan 'käyttömusiikin' tutkimista kansanmusiikista aina jazziin. (Järviluoma 2001, 68.)

Ala-Könni oli tuonut esiin näkemyksiään jo vuonna 1969, jolloin hän toimi Suomen Pelimanniyhdistyksen puheenjohtajana ja laati yhdessä Matti Pihlaston ja Sirkka Viitasen kanssa julkilausuman, jossa kritisoitiin konserttimusiikin tukemista julkisin varoin. Julkilausumassa todettiin, kuinka

kotoisen kansamusiikin ja laajalti harrastetun käyttömusiikin opetus on samalla jäänyt hoitamatta. Tästä johtuu monenlaisia haittailmiöitä ja puutteita. Laiminlyönnit ovat aiheuttaneet sen, että olemme jääneet musiikkikulttuurissa p.o. sektorin osalta Euroopan takapajuisempien maiden joukkoon. Rikas kansallinen sävelmistömme näyttää julkisen tuen puutteessa odottavan turhaan löytäjäänsä. (NEFA, Julkilausuma 1969.)

Perustelut kansanmusiikin ja 'käyttömusiikin' opettamiselle ja tutkimukselle palautuvat siis jälleen Ala-Könnin tiiviisiin suhteisiin kentälle, Suomen Pelimanniyhdistys (myöhemmin Suomen Kansanmusiikkiliitto) oli Suomen Nuorison Liiton alun perin perustama harrastusjärjestö, joka kokosi yhteen kaikenikäisiä soittajia ympäri Suomea.

On kuitenkin oletettavaa, että Ala-Könnin ajattelua siivitti myös Suomessa tuolloin käynnissä ollut laajempi yhteiskuntapoliittinen ja sosiaalipoliittinen keskustelu. Haastattelussa (Kper Y08720) hän nostaa esiin useaan otteeseen halunsa luoda monitieteinen oppiaine. Yhteiskuntatieteellisiä vaikutteita hän oletettavasti sai Pekka Kuusen (1961) ja Heikki Wariksen (1961) tutkimuksista, jotka saivat ajankohtana paljon julkisuutta. Kuten Järviluoma $(2001,68)$ tulkitsee, Ala-Könnille etnologiset kysymykset olivat sosiologisia kysymyksiä. 1960-luvun yhteiskunnallinen tilanne: kaupungistuminen ja liikkuvuuden lisääntyminen sekä siitä käyty keskustelu oli se laajempi viitekehys, johon Ala-Könni halusi "populaaria" koskevan tutkimuksensa asettaa. Tämä sosiologisesti virittynyt katsantokanta aktiivisen kentällä toimimisen ohella erotti Ala-Könnin vanhemman polven kansatieteilijöistä ja kansanmusiikintutkijoista. Sen sijaan yhtymäkohtia on mahdollista nähdä kansanrunouden tutkimuksen uudistajana tunnetun Matti Kuusen ajatteluun (ks. Häggman 2015, 173-178), vaikka esimerkiksi haastattelussa Ala-Könni (Kper Y08720) ei tuo näitä yhteyksiä esille. 
Edellä kuvatusta prosessista löytyy etnomusikologian kotouttamisen maaperä, jota Ala-Könni aktiivisesti työsti ja jota voidaan tulkita myös metodologisen nationalismin näkökulmasta. Työtä siivittivät Kansallisten tieteiden kehittämisohjelmassa (KTK 1965) kirjatut periaatteet suomalaisen kansankulttuurin keräämisestä ja säilyttämisestä. Näitä Ala-Könni oli muokannut omaan toimintaansa sopivaksi: hän toimi aktiivisesti tutkimuskentällä ja halusi rakentaa monitieteistä ja "praktista" oppiainetta. Ajattelutapaa tukivat ajan merkittävien sosiaalipoliitikkojen puheenvuorot suomalaisen yhteiskunnan sosiaalisesta rakenteesta ja siihen sisältyvistä ongelmista. Voidaan väittää, että juuri tässä tilanteessa etnomusikologian kotouttaminen tapahtui, kansallisten tieteiden ja uusien yhteiskuntaa koskevien näkemysten jännitteisessä kohtaamisessa ja yhteen nivoutumisessa. Kuitenkin se, millainen artikulaatio lopulta muodostui, on oma kysymyksensä.

Käsite etnomusikologia nousi esiin siinä vaiheessa kun ajankohtaiseksi tuli professuurin ja muiden opetusvirkojen hankkiminen Tampereen yliopistoon 1970luvun alkuvuosina. Alkuvaiheessa oppialaa määrittelevät tehtävänimikkeet vaihtelivat suurestikin. Hyvä esimerkki tästä on vuoden 1972 lopussa käyty kiista, jossa opetusministeri tarjosi Sibelius-Akatemialle kahta sivutoimista lehtoraattia jazzin ja etnomusikologian opetukseen. Akatemia ei näitä virkoja kuitenkaan halunnut, vaan totesi muun muassa että "etnomusikologia merkitsisi kaiken kansainvälisen kansanmusiikin huomioon ottamista, suomalainen jäisi vähemmälle" (OA 1972). Lisäksi todettiin, kuinka "kansanmusiikilla ei ole pohjaa Helsingissä". Kieltäytymisen voi ymmärtää niin, että etnomusikologia ja jazz eivät sopineet konservatiivisen Sibelius-Akatemian opetusohjelmaan. Toisaalta perustelu "kansanmusiikilla ei ole pohjaa Helsingissä" kuvaa sitä, kuinka konkreettiseksi raja agraari-Suomen ja pääkaupunkiseudun välillä miellettiin.

Koska ministeriöllä oli intressi virkojen perustamiseen, koolle kutsuttiin erillinen työryhmä ratkaisemaan tilannetta. Tähän ryhmään kuuluivat muun muassa maakuntaneuvos Viljo S. Määttälä ja Erkki Ala-Könni. Määttälä oli ollut pitkään keskeinen tuki Ala-Könnille ja omistautui vähintään yhtä vahvasti ajamaan kansamusiikin ja -kulttuurin aseman parantamista kuin Ala-Könni. Hän myös korosti paikalliskulttuurin merkitystä maaseudun elävöittämisessä. Ryhmän ehdotuksesta Sibelius-Akatemialle annettiin vapaus perustaa omavalintainen lehtoraatti, mutta Tampereelle ehdotettiin aluksi kansanmusiikin lehtoraattia, tosin myöhemmin samassa dokumentissa nimi oli muuttunut etnomusikologian lehtoraatiksi. Kansanmusiikki ja etnomusikologia kilpailivat siten tasavahvoina nimiehdotuksina dokumenteissa. Lisäksi opetettaviksi aineiksi nimettiin jazz, iskelmä ja musiikkisosiologia. (OA 1972.)

Edellä kerrottu osoittaa, kuinka Tampereen oppiaineen profiilin määrittämistä koskeva keskustelu ja merkityksenanto sisälsivät paljon kelluvia elementtejä (ks. Laclau \& Mouffe 1985, 66) ja etnomusikologia oli yksi niistä, sillä ei ollut vielä kovinkaan tarkkaa positiota tai sisällöllistä määrittelyä. Hegemoninen kamppailu oli kuitenkin kytemässä, ja se kulminoitui uuden professuurin oppialan määrittämiseen. Tässä keskustelussa oppiaineen merkitystä ryhdyttiin ankkuroimaan suomalaisen kansanmusiikin tutkimuksen suuntaan. Keskustelu alkoi vuonna 1971, jolloin etnomusikologiaa Yhdysvalloissa opiskellut Pekka Gronow (1971) vaati lehtikeskusteluissa 
"kansanmusiikin tieteellisen tutkimuksen järjestämistä ja käytännön päämääriin tähtäävän opetuksen alullepanoa". Gronow oli 1960-luvun lopulla osallistunut aktiivisesti suomalaista musiikkipolitiikkaa koskevaan keskusteluun ja peräänkuulutti analyyttista ja järkiperäistä, kontekstuaalista tarkastelutapaa musiikkiin (Rautiainen 2001, 139-145), mutta nyt hän alkoi ponnekkaasti ajaa kansanmusiikin tutkimuksen edellytyksien parantamista.

Gronowin motiivit liittyvät 1970-luvun kulttuuripoliittiseen keskusteluun, jossa kaupalliskriittiset näkemykset alkoivat korostua ja 1960-luvun kulttuurin moniarvoisuuden vaatimus katosi vähin erin keskustelusta. Tämä tuli näkyviin myös päivänpolitiikassa. Vuonna 1973 silloinen keskustalainen opetusministeri Marjatta Väänänen puhui kansanmusiikin merkityksestä Kaustisen kansanmusiikkifestivaalien avajaispuheessa. Kansanmusiikki oli hänelle yhtenäistävän viihteen, populaarikulttuurin, tärkeä vastapooli. Keskeistä oli se, että kansamusiikki aktivoi ihmisiä toimimaan. Väänänen viittasi puheessaan myös Ranskan silloiseen kulttuuriministeriin André Malraux'hon, jolla oli keskeinen rooli valtiojohtoisen ja kaupallisuuteen kriittisesti suhtautuvan kulttuuripolitiikan luomisessa Ranskassa:

Tämän päivän yhteiskunnan ongelma on massoittuminen ja liiallisen yhtenäistymisen vaara. Tiedotus- ja liikennevälineiden kehittyessä kansainvälinen vuorovaikutus on voimakkaasti lisääntynyt. Tämä on merkinnyt ihmisten kulttuuriharrastusten laajentumista ja monipuolistumista ja yksilöille mahdollisuutta kulttuuripääoman kasvattamiseen. Mutta siihen on sisältynyt oma vaaransa. Se saattaa merkitä myös kulttuurien samanlaistumista ja kansallisten kulttuurien erityisleiman häviämistä. Se on merkinnyt yleiskulttuurin massaviihteen tunkeutumista kaikkialle, ja tämä puolestaan on aikaansaanut omatoimisen harrastuksen ja toiminnan vähenemisen. Ihmisistä on tulossa massaviihteen passiivisia seuraajia aktiivisten kulttuurintekijöiden vähetessä. Tämän on ilmaissut muun muassa Ranskan kulttuuriministeri Andre Malraux eräässä Suomessa pitämässään puheessa, kun hän totesi: "On kehittynyt valtava viihdytysteollisuus, joka tuottaa koneellisesti unelmia kaikille yhteiskuntaluokille. Tällä hetkellä on olemassa huviteollisuus myös proletariaattia varten." Tässä vaiheessa kansanmusiikin harrastus, joka pohjautuu oman kansan perinnekulttuuriin, merkitsee vastavoimaa Malraux'n mainitsemalle kehitykselle ja se on voimistuessaan merkinnyt omaehtoisen, luovan toiminnan lisääntymistä. Nämäkin juhlat ovat antaneet tästä lukuisia näytteitä. Omien soitteiden säveltäminen tai laulujen sepittäminen ja niiden esittäminen on osoitus kulttuuriaktiivisuudesta, joka ei halua tyytyä passiivisen seuraajan rooliin." (NEFA, Väänänen 1973.)

Väänäsen puhe vihjaa siihen, että Ala-Könnin pyrkimys nivoa populaarin tutkimusta yhteiskuntatieteisiin kansainvälisen tutkimusalan taustatuella ei saanut tulta alleen. On myös vaikea sanoa, kuinka pitkälle Ala-Könni edes itse sitoutui tähän projektiin. Kysymys traditiosta nousi entistä vahvimmin esiin. Tämä selittyy nähdäkseni pitkälti sillä, että Ala-Könnin tiiviit suhteet harrastajakenttään ja sieltä tuleviin intresseihin sekä moniarvoinen ja monialainen musiikintutkimus eivät kaikilta osin kohdanneet toisiaan.

Vuonna 1974 Marjatta Väänäsen ministerikaudella professuurihanke menikin vihdoin läpi nimikkeellä "kansanperinne, erityisesti kansamusiikki". Siihen, miten juuri tähän nimimuotoiluun päädyttiin, liittyy paljon selvittämätöntä, mutta olettaa voi, että opetusministerillä oli tässä merkittävä rooli. Kansamusiikkia tuli tukea 
Tarja Rautiainen-Keskustalo: Kansalliset tieteet, etnomusikologia ja...

[http://www.elore.fi/arkisto/2_15/rautiainen-keskustalo.pdf]

moniarvoisuuden nimissä "vastapainona kasvavalle jazz- ja bändiharrastukselle" kuten ministeri puheessaan olikin todennut (NEFA, Väänänen 1973).

Nimitys herätti ihmetystä perinnetieteiden piirissä, sillä sen nähtiin heikentävän jo olemassa olevien laitosten asemaa. Voimakkaimmin kantaa otti Ilmar Talve (1973), joka Turun yliopiston kansatieteen laitoksen Informaatio-lehdessä piti uuden oppiaineen määrittelyä "hämäränä":

Oppiaineen nimenä pelkkä kansanperinne ei riitä, koska yleensä yliopistoissa käytetään lisämäärittelyä "oppi", "tiede" t. "tutkimus". Muutenkaan uusi nimitys ei ole perusteltu koska Suomessa on jo ennestään käytössä sekä "kansatiede" (Helsinki, Turku), "kansanelämäntutkimus" (Jyväskylä, Åbo Akademi: "folklivsforskning") ja myös etnologia (Jyväskylän yliopisto etnologian laitos ja Helsinki: etnologian dosentti). (Talve 1973.)

Ala-Könni (Kper Y08720) sanoo haastelussaan, ettei hänellä ollut mitään käsitystä, miten "kansanperinne erityisesti kansanmusiikki" -muotoiluun päädyttiin, mutta spekuloida voi sillä, missä määrin Ala-Könnin eronteko perinnetieteisiin nähden oli päätöksen taustalla. Ilmar Talve (1973) vihjaa artikkelissa siihen, että taustalla olisi ollut valtataisteluja: "Ei voi välttyä vaikutelmalta, että kansanmusiikin opetuksen varjolla ja sekin huomioiden on lähdetty perustamaan uutta oppituolia, jota ei korkeakouluneuvosto eikä Tampereen yliopisto ole ehdottanut. Mihin tarpeeseen ja kenen toimesta?"

Nimitys kuitenkin hyväksyttiin ja samalla etnomusikologia ankkuroitui 1970-luvun kaupalliskriittiseen maaperään. Moniarvoisuuden retoriikka, joka oli lähtenyt liikkeelle sosiaalipoliittisesta maaseutu-kaupunki -asetelmasta, sai nyt kulttuuriteollisuutta kritisoivia piirteitä. Kulttuuriteollisuuden nähtiin manipuloivan väestöä tuottaessaan ja levittäessään kulttuuritavaroita joukkotiedotusvälineiden kautta. Myöhemmin kulttuurin kaupallisuuden kritiikki muodosti suomalaisen hyvinvointivaltion kulttuuripolitiikan ytimen eli sen, että kulttuurille asetettiin kansallisessa kulttuuripolitiikassa kolme määrettä: sen tuli olla kansallista, ei-kaupallista ja kasvattavaa (Rautiainen 2001, 139-140).

\section{SÄILYTTÄVÄ JA AKTIVOIVA ETNOMUSIKOLOGIA?}

Voidaan siis väittää, että oppiaineen perustamisprosessia ja etnomusikologian määrittämistä Tampereella ohjasi osaltaan kansallinen katse, metodologinen nationalismi, joka oli yhdistelmä kansallista katsetta ja syntymässä olevaa protektionistista kulttuuripolitiikkaa. Käsitteenä metodologinen nationalismi kuulostaa helposti kritiikiltä ja jopa halventavalta, mutta kuten Kettunen $(2008,16)$ toteaa, se tulisi ymmärtää ajan olosuhteista käsin: kansallisvaltiollinen viitekehys oli toiminnan itsestään selvä ja kyseenalaistamaton lähtökohta. Toisaalta ajattelutapa ei ohjannut vain pientä oppiainetta, vaan autonominen yliopistolaitos nojasi sekin metodologiseen nationalismiin pitäessään pieniä kansallisia oppialoja tärkeinä, eikä asettanut toiminnalle juurikaan ehtoja. Kuten Kettunen (2008) osoittaa, metodologinen nationalismi oli viime kädessä toiminnan kehys koko suomalaiselle hyvinvointivaltiolle aina 1980-luvulle asti ja sen jälkeenkin, vaikka globalisaatio on ajanut sen monin tavoin kriisiin. 
Miten kansallinen katse tuli esille tamperelaisen etnomusikologian määrittelyissä? Ensinnäkin siinä, että Erkki Ala-Könnin hahmo ja hänen keräämänsä arkistoaineisto loivat toiminnalle moraalisen pohjan, oppiaineen perusta oli arkiston kansanperinnekokoelmissa. Oppiaineessa pidettiinkin oman kokemukseni mukaan tärkeänä arkistoon liittyvän opetuksen antamista aina itsenäisen laitoksen lakkauttamiseen saakka. Tätä kautta välittyi myös perinteen keräämisen ja säilyttämisen keskeisyys. Toisaalta opiskelijoilla odotettiin olevan melko itsestään selvästi kiinnostusta suomalaiseen kansamusiikkiin ja -perinteeseen. Arkiston tiivis nivominen etnomusikologian opetukseen oli myös suurin ero suhteessa muihin Suomen yliopistoihin, joissa annettiin etnomusikologiaan liittyvää opetusta. 1980-luvun lopulle asti tämä tarkoitti Helsingin yliopistoa, jossa oli mahdollista suorittaa etnomusikologiaan liittyviä kursseja. Siellä etnomusikologian opetuksen lähtökohta oli kuitenkin lähtökohdiltaan yleisantropologinen. 1990-luvun alusta lähtien musiikintutkimuksen kenttä laajeni nopeasti ja niin kutsutun kulttuurisen musiikintutkimuksen myötä lähes kaikissa suomalaisissa musiikkitieteen laitoksissa ryhdyttiin opettamaan etnomusikologisen tutkimuksen perusteita yhdessä populaarimusiikin tutkimuksen kanssa. Opetuksen lähtökohta on kuitenkin myös näissä laitoksissa ollut antropologinen, ei perinnetieteisiin kiinnittyvä.

Toinen kansallisen katseen piirre, joka perustui Ala-Könnin toiminnan luonteeseen, oli praktisuuden, käytännönläheisyyden korostaminen opetuksessa. Tästä kertoo Ala-Könnin (Kper Y08720) haastattelussa esiin nostama pyrkimys nivoa opetusohjelmaan kokonaisuuksia niin kansamusiikintutkimuksesta, musiikkitieteestä, folkloristiikasta kuin kansatieteestä, jotta se perehdyttäisi tulevia kulttuurihallinnon ja lehdistön ammattilaisia nimenomaan suomalaiseen kulttuuriin ja saisi heitä hyödyntämään kansanperinnettä työssään. Käytännönläheisyyden korostaminen, joskus tutkimuksen kustannuksellakin, oli piirre, joka erotti oppiainetta muista perinnetieteistä, vaikka horisontissa häämötti eittämättä molempia yhdistänyt käsitys suomalaisesta yhtenäiskulttuurista, mahdollisuudesta rakentaa topografia Suomen kansasta (Knuuttila 2008, $456-458$ ).

Opiskelijoille tämä ruohonjuuritason toiminnan korostaminen välittyi saumattomasti. Kun itse ryhdyin opiskelemaan Kansanperinteen oppiaineessa 1980-luvun puolessavälissä vuoden kestäneiden yhteiskuntapolitiikan opintojen jälkeen, vanhempien opiskelijapolvien aktiivisuus erilaisten musiikkitapahtumien innovoimisessa ja toteuttamisessa oli kokonaan uusi elementti akateemisissa opinnoissa.

On syytä korostaa, että kysymys ei tässä ole kritiikistä tai jälkiviisastelusta, jota mennyttä aikakautta kohtaan on helppo esittää. Pikemminkin kansakuntainen katse on hedelmällisempää ymmärtää Kettusen (2008) tapaan yleisenä viitekehyksenä, joka on tavalla tai toisella ollut läsnä ainakin Tampereella etnomusikologiaa opiskelleiden parissa. Esimerkiksi tämän artikkelin kirjoittajan opinnäytetyöt (Rautiainen 1992, 1997 ja 2001) ovat syntyneet "omaan" perinteeseen kohdistuvan katseen vaikutuksessa.

Toisaalta en väitä, että Ala-Könni olisi suoranaisesti luopunut pyrkimyksestään laaja-alaiseen musiikkikulttuurin tarkasteluun. Opetusohjelmasta löytyi hänen professuurikaudellaan kursseja populaarimusiikista ja vieraiden kansojen 
musiikkikulttuureista (Järviluoma 2001, 65). Mutta kuten olen edellä todennut, toiminnan moraalinen, ääneen lausuttu perusta oli viime kädessä kansallisen kulttuurin tallettaminen ja vaaliminen.

1980-luvulta lähtien, Ala-Könnin jäätyä eläkkeelle, kansalliseen katseeseen nivoutuivat Tampereella yleisantropologiset etnomusikologian klassikot, soveltavan etnomusikologian piirteet ja lopulta, vuosikymmenen lopulla, populaarimusiikin ja kulttuurintutkimuksen kansainväliset virtaukset. Viimeistään tuossa vaiheessa etnomusikologia avautui siis laaja-alaisena kenttänä erilaisia lähestymistapoja ja tutkimusintressejä, mutta edelleen toimintaa perusteltiin viime kädessä Ala-Könnin perinnöllä.

Avoin suhtautumistapa kuvasi laajemminkin suomalaisen etnomusikologian luonnetta: katto korkealla, seinät leveällä -lähestymistapa on saanut aikaan sen, että kovin vahvoja koulukuntia ei ole muodostunut, lukuun ottamatta musiikki- ja kulttuurianalyyttisten näkökulmien ajoittaista vastakkainasettelua (Kytö \& Rantanen 2014, 15-16). Vahvojen koulukuntien puuttuminen on ollut osin resurssikysymys, sillä esimerkiksi yhdysvaltalaisten etnomusikologian opinahjojen opetussuunnitelmia ei missään vaiheessa ole ollut Suomessa mahdollista toteuttaa. Toisaalta hyvinvointivaltio yhteisten intressien neuvottelukenttänä (Kettunen 2008, 136) vahvisti etnomusikologian luonnetta yhteiskunnallisena liikkeenä. Tämän päivän perspektiivistä onkin helppo nähdä, kuinka etnomusikologinen tutkimus osaltaan pyrki rakentamaan siltaa modernin ja tradition välille korostamalla musiikillista moniarvoisuutta ja osoittamalla ongelmakohtia suhtautumistavoissa tai vaikkapa resurssien jakamisessa. Esille nostettiin esimerkiksi vähemmistöjen musiikkiperinteet, harrastajamuusikot, populaarimusiikin vähäinen arvostus.

Kaikki on kuitenkin näyttänyt muuttuvan vuoden 2010 jälkeen. Kansallisvaltioon ja erityisesti etnisyyteen liittyvät kysymykset olivat politisoituneet uudella tavalla samanaikaisesti kun valtion harjoittamaa politiikkaa, myös korkeakoulupolitiikkaa, ei ole enää ohjannut niinkään hyvinvointivaltioprojekti vaan pikemminkin kilpailutalous. Etnomusikologisen tiedon paikka on ikään kuin hävinnyt; kansalliselle katseelle ei ole löytynyt enää tukea samalla tavalla kuin aiemmin. Vaikka edellä kuvatun pohjalta on mahdollista väittää, että kansallinen katse on ollut vain yksi osa etnomusikologian määrittymistä Tampereen yliopistossa, on se kuitenkin ollut se osa, jolla oppialaa on ulospäin ollut vahvimmin tapa perustella.

\section{LIIKKUVA MAAILMA JA ETNOMUSIKOLOGIA}

Michel Denning toteaa kirjassaan Culture In the Age of Three Worlds (2004), kuinka kulttuuri on tänä päivänä arkielämän konteksti, 'ilma jota hengitämme'. Jos aiemmin kulttuuri pyrittiin kirjoittamaan isolla kirjaimella - mikä on nähtävissä esimerkiksi Kansallisten tieteiden kehittämäohjelman sivulta - näin ei enää juuri tehdä. Projekti, joka pyrki kansallisvaltiollisessa viitekehyksessä piirtämään kartalle "suomalaista kulttuuria" on muuttunut monella tapaa ongelmalliseksi tehtävänasetteluksi.

Kulttuuri näyttäytyy tämänhetkisessä keskustelussa liikkuvana, toimintana, joka muovaa asioita. Käsite toki luokittelee ja edelleenkin arvottaa, mutta ei paikanna 
kulttuuria selvärajaiseen tai autonomiseen kategoriaan, esimerkiksi korkeaan tai kansalliseen. Tämä ei kuitenkaan merkitse sitä, että modernin jäsennykset olisivat hävinneet (vaikkapa kansallisen kulttuurin tai perinteiset korkean ja matalan kulttuurin kategoriat). Ne elävät paikoitellen hyvinkin vahvoina, törmäävät ja nivoutuvat uusiin paikannuksiin ja merkityksenantoihin, joita ovat luomassa taloudelliset, uskonnolliset ja etniset konfliktit sekä toisaalta digitaalisen kulttuurin käytänteet.

Vaikutelma, että etnomusikologisella tiedolla ei olisi yhteiskunnallista paikkaa, on ymmärrettävissä liikkuvan maailman metaforan näkökulmasta. Kulttuurin käsitteen temaattinen hajoaminen on tuonut etnomusikologiselle tutkimukselle haasteen, eteenkin jos etnomusikologia ymmärretään kansojen musiikin tutkimukseksi. Kansan tai etnisyyden ottaminen tutkimuksen lähtökohdaksi ylirajaisessa maailmassa ei ole ongelmatonta, sillä jo nimeäminen itsessään on politisoitunut. Tässä onkin suurin ero suhteessa menneeseen: siinä missä 1970-luvun etnomusikologian kansapuhe suuntautui etsimään ensisijassa aitoa ja alkuperäistä (kaupallisen kulttuurin vastapainona) ilman etnisyyteen liittyvää vastakkainasettelua tai vertailuasetelmia, tänä päivänä kansapuhe asettuu hetkessä poliittiseksi kysymykseksi, koska etnisyys ja alkuperä ovat muuttuneet reaaliseksi arkipäivän kamppailujen kentäksi. Anna Rastaan (2013) esimerkki afrikkalaisten diasporaan asettuvien ihmisten ja ryhmien nimeämisestä ja siihen liittyvästä kamppailusta kuvaa tätä hyvin. Esimerkiksi Suomessa asuvien afrikkalaisyhteisöjen kesken ei ole yksimielisyyttä siitä, kuinka kuvata afrikkalaisia sukujuuria jos ei vaikkapa haluta viitata lähtömaahan tai kansallisuuteen, mikä taas usein voi olla tärkeää yleisten ennakkoluulojen välttämiseksi.

Usein tilanne on myös se, että sanoja ei yksinkertaisesti ole oman erityisyyden ja aseman määrittelyyn suhteessa ympäröiviin rodullistettuihin suhteisiin (Rastas 2013, 169). Nimeämisen ongelmallisuudesta on kirjoittanut myös Laura Huttunen (2013) pohtiessaan sitä, kuinka kirjailijan määrittyminen "maahanmuuttajakirjailijaksi" alkaa helposti ohjata teosten lukutapaa. Samalla tavalla voidaan ajatella, että maahanmuuttajuus muusikon leimana synnyttää helposti rajaavan toiminnan kehyksen.

Etnomusikologian ja erityisesti soveltavan etnomusikologian tehtäväksi usein miellettyä tietyn musiikkikulttuuriin tai etnisen ryhmän puolesta puhumista (esim. Moisala 2013, 17-19) ei siis voi pitää ongelmattomana, koska tällöin tutkija joutuu väistämättä nimeämiskamppailujen kentälle ja kamppailujen hahmottamisessa tarvitaan perinteistä etnografista tutkimusta laajempaa yhteiskuntatieteellistä viitekehystä. Tämä perspektiivin laajentuminen on nähtävissä etnomusikologian postkolonialistissa suuntauksissa (esim. Guilbault 2007), mutta yhä edelleen teoreettisessa ajattelussa kaivataan uusia työkaluja ja lähestymistapoja.

Etno-etuliitteen politisoituminen näkyy myös siinä, että kansalliseen perinteeseen liittyvät merkityksenannot ruokkivat helposti kansallismielistä liikehdintää. Kovin näkyvää tämä ei ole toistaiseksi ollut, mutta esimerkkejä löytyy niin Suomesta kuin Britanniastakin. Esimerkiksi Heidi Haapoja (2013) on tutkinut sitä, kuinka suomalaisten medioiden (myös sosiaalisen median) puhetavoista löytyy metodologisen nationalismin juonne, kansallisen ja "meidän" perinteen korostaminen kalevalamittaisesta 
nykyrunolaulusta puhuttaessa. Sosiaalisessa mediassa kannanotot ovat olleet kärjekkäämpiä. Esimerkkinä Haapoja (mts, 16-17) mainitsee Keskustan kansanedustaja-avustajan Jaakko Kyllösen, joka vuonna 2013 vaati "Frontside Ollien heittämistä romukoppaan" ja kansanlaulujen palauttamista arvoonsa. Kyllösen kannanotot olivat avoimen kansallismielisiä:

Suurella rahalla rakennettu Helsingin Musiikkitalo tehtiin musiikin ystävien ja muusikoiden tarpeisiin. Mutta missä ovat isänmaalliset kansanlaulut? Musiikkitalon ohjelmiston täyttää valitettavasti monikulttuurinen musiikki. (Kyllönen 2013.)

Myös Perussuomalaisten kansanedustaja Olli Immonen (2013) on vaatinut julkisen kulttuurirahoituksen suuntaamista yksinomaan kansallisen kulttuuriperinnön säilyttämiseen. Ilmiö koskee koko Länsi-Eurooppaa. Esimerkiksi Britanniassa British National Party -puolue julkaisi vuonna 2008 kansanmusiikkia sisältävän CD:n ja kehotti inmisiä vaalimaan englantilaisen kansankulttuurin tapoja ja juhlia "kasvavaa islamilaista voimaa vastaan" (BBC News 2015).

Millaiseksi etnomusikologinen tutkimus voisi sitten määrittyä suhteessa liikkuvan maailman käsitteeseen? Nähdäkseni kysymys on edelleen musiikin tutkimuksesta kulttuurina ja kulttuurissa, mutta ei niin että musiikki (kuten ei myöskään kulttuuri) olisi lokero, jota määrittää esimerkiksi etnisyys, vaan pikemminkin musiikki on ensi sijassa toimintaa ja käytäntöjä. Tätä ajattelutapaa ehdottaa myös Mikko Lehtonen (2014b, 319), joka on todennut kuinka kulttuurin tutkiminen ei voi olla vain kulttuuristen symbolien tarkastelua, vaan pikemminkin kulttuurintutkijoiden tehtävä hahmottuu "kulttuuriksi kutsuttujen inhimillisten toimien praktisuuden ja vaikuttavuuden tutkimukseksi". Tämän pohjalta etnomusikologian tutkimuksen lähtökohdaksi voisi määrittyä musiikin tutkiminen arkielämän resurssina, materiaalis-symbolisena toiminnan muotona, jonka avulla inmiset tekevät identiteettipolitiikkaa ja tuottavat eroja eri ihmisryhmien välille sekä kokevat ja elävät arkipäiväänsä.

Erityistä musiikin osalta on se, että musiikkia tarkasteltaessa kaikki edellä kuvatut materiaalis-symbolisen toiminnan muodot ulottuvat ruumiillisiin kokemuksiin ja affekteihin. Tällöin olisi mahdollisuus vapautua siitä, että musiikki tulisi asettaa muusta toiminnasta erilliseksi. Se kyllä toimii erityisellä tavalla usein sanojen ulottumattomissa, mutta erityisyys ei tarkoita sitä, että musiikki asetettaisiin erilleen muusta sosiaalisesta toiminnasta.

Sinällään tässä hahmotuksessa kysymys ei ole uuden paradigman julistamisesta - liikkuvan maailman käsitteen kautta hahmotettuna kulttuurista ja kulttuurin liittyvistä arvoista käytävä kamppailu tekee sen mahdottomaksi. Kansallisten tieteiden kehittämisohjelman aikoihin kansallinen kulttuurin käsite ilmensi julkilausumatonta yhtenäistä arvopohjaa ja moraalia. Nyt tuota yhteistä käsitystä ei ole, mutta tarve sen löytämiselle on ilmeisen suuri tämän päivän yhteiskunnassa: kuka olen, mistä tulen ja mihin kuulun ovat kysymyksiä, joita tässä ajassa yhä kysymme. Kuten Andrew Whelan (2014) on todennut, musiikin kautta ja musiikin avulla teemme ennen kaikkea moraalista työtä eli pyrimme vastaamaan identiteettiä koskeviin kysymyksiin ja samalla peilaamme erilaisia arvoasetelmia toisiinsa. 
Tarja Rautiainen-Keskustalo: Kansalliset tieteet, etnomusikologia ja...

[http://www.elore.fi/arkisto/2_15/rautiainen-keskustalo.pdf]

Etnomusikologin haasteena onkin hahmottaa ja ymmärtää näiden moraalisten rihmastojen reittejä ja vaikutuksia.

\section{LÄHTEET}

\section{Opetusminsterion arkisto (OA)}

Asiakirjat:

OA 1972: Sibelius-Akatemian kahden lehtoraatin täyttäminen. Tampereen yliopisto, Kansaperinteen arkisto (Kper)

Kper, Lehtileikekokoelma (leikekirjat).

Äänitteet:

Kper Y08720: Erkki Ala-Könnin haastattelu 24.8.1981 Tampereella. Haastattelija:

Erkki Moisio.

\section{Tampereen yliopisto, NEFA-Tampere -ainejärjestön arkisto (NEFA)}

Asiakirjat:

NEFA, Julkilausuma 1969: Suomen Pelimanniyhdistyksen vuosikokous Niittylahdessa 26.6.1969.

NEFA, Väänänen 1973: Marjatta Väänäsen puhe Kaustisen kansanmusiikkijuhlilla 1973.

KiRJALLisUUS

Ala-Könni, Erkki 1956: Die Polska-Tänze in Finnland: eine ethno-musikologische Untersuchung. Helsinki: [Suomen muinaismuistoyhdistys].

Alasuutari, Pertti \& Quadir, Ali (eds.) 2014: National Policy-Making: Domestication of Global Trends. London: Routledge.

Alasuutari, Pertti 1996: Toinen tasavalta. Suomi 1946-1994. Tampere: Vastapaino.

Anttonen, Pertti J. 2005: Tradition through modernity. Postmodernism and the Nation-State in Folklore Scholarship. Helsinki: SKS.

BBC News 2015: Musicians fight to keep politics out of folk 2009. - BBC News 8.8.2009. [online] < http://news.bbc.co.uk/2/hi/uk/8191094.stm > [17.11. 2015.]

Beck, Ulrich 1999: Mitä globalisaatio on? Virhekäsityksiä ja poliittisia vastauksia. Tampere: Vastapaino.

Denning, Michael 2004: Culture in the Age of Three Worlds. London: Verso.

Gronow, Pekka 1971: Keskustelua. Kansanmusiikin tulevaisuus. - Helsingin Sanomat 8.8.1971.

Guilbault, Jocelyne 2007: Governing Sound. The Cultural Politics of Trinidad's Carneval Musics. Chigaco: The University of Chicago Press. 
Tarja Rautiainen-Keskustalo: Kansalliset tieteet, etnomusikologia ja...

[http://www.elore.fi/arkisto/2_15/rautiainen-keskustalo.pdf]

Haapoja, Heidi 2013: "Jatkuvassa liikkeessä on myös koko kalevalainen perintömme". Nykyrunolauluun liittyvät puheen tavat suomalaisissa medioissa. - Elore 20(2): 10-32 [online] < http://www.elore.fi/arkisto/2 13/haapoja.pdf $>$ [13.8. 2015].

Huttunen, Laura 2013: Improvisointi, kitka ja kulttuurin käsitteellistäminen. - Lehtonen, Mikko (toim.), Liikkuva maailma: Liike, raja, tieto. Tampere: Vastapaino. 245-260.

Häggman, Kai 2015: Pieni kansa, pitkä muisti: Suomalaisen Kirjallisuuden Seura talvisodasta 2000-luvulle. Helsinki: SKS.

Immonen, Olli 2013: Kulttuuripolitiikan vahvistettava suomalaista identiteettiä. - Yle uutiset 22.3.2013. [online] < http://yle.fi/uutiset/olli immonen kulttuuripolitiikan vahvistettava suomalaista identiteettia/6546929 $>$ [11.8. 2015.]

Järviluoma, Helmi 2001: Kansanmusiikki oppituolille - rajankäyntityön historiaa 1965-1983. - Musiikki 31(1):65-79.

Järviluoma, Helmi \& Saloniemi, Marjo-Riitta 1988: "Muistin lokerot auki - teitäkin saatetaan haastatella": näkökulmia Tampereen yliopiston kansanperinteen laitoksen pitäjäkeräelmiin. - Musiikin Suunta (10)1: 28-40.

Kettunen, Pauli 2008: Globalisaatio ja kansallinen me. Kansallisen katseen historiallinen kritiikki. Tampere: Vastapaino.

Knuuttila, Seppo 1994: Tyhmän kansan teoria. Näkökulmia menneestä tulevaan. Helsinki: SKS.

Knuuttila, Seppo 2008: Sankariaika suomalaisessa kansanrunoudentutkimuksessa 1930-luvulla. - Knuuttila, Seppo, Entinen aika, nykyinen mieli. Helsinki: SKS. 444-469.

Koiranen, Antti \& Leisiö Timo \& Saha Hannu 2003: Kansanmusiikin tutkimus Suomessa. - Eerola, Tuomas \& Louhivuori, Jukka \& Moisala, Pirkko (toim.), Johdatus musiikintutkimukseen. Helsinki: Suomen Musiikkitieteellinen seura. 113-130.

KTK 1965: Kansallisten tieteiden kehittämisohjelma 1966-1980. Helsinki: SKS.

Kukkurainen, Eija 1983: Erkki Ala-Könni kahdeksannella vuosikymmenellään. Mattila, Pekka \& Koiranen, Antti \& Lehtimäki, Pekka \& Nallinmaa, Eero (toim.), Kentältä kentälle. Juhlakirja Erkki Ala-Könnin 70-vuotispäiväksi 2.2.1981. Tampere: Tampereen yliopiston kansanperinteen laitos. 9-14.

Kurkela, Vesa \& Leisiö, Timo \& Moisala, Pirkko 2003: Etnomusikologia. Eerola, Tuomas \& Louhivuori, Jukka \& Moisala, Pirkko (toim.), Johdatus musiikintutkimukseen. Helsinki: Suomen Musiikkitieteellinen seura. 53-70.

Kuusi, Pekka 1961: 60-luvun sosiaalipolitiikka. Helsinki: WSOY.

Kyllönen, Jaakko 2013: Frontside Olliet joutavat romukoppaan. - Ilkka 20.4.2013 [online] < http://www.ilkka.fi/mielipide/yleis\%C3\%B6lt\%C3\%A4/frontsideolliet-joutavat-romukoppaan-1.1375627) > [11.8.2015.]

Kytö, Meri \& Rantanen, Saija-Leena 2014: Etnomusikologian vuosikirjan merkitys musiikintutkimuksen alalle Suomessa. - Etnomusikologian vuosikirja 26: 8-25.

Laclau, Ernesto \& Mouffe, Chantal 1985: Hegemony and Socialist Theory. Towards a Radical Democratic Politics. London: Verso.

Lehtonen, Mikko 2013: Miten tutkia liikkuvaa maailmaa? - Lehtonen, Mikko (toim.), Liikkuva maailma. Tampere: Vastapaino. 7-29. 
Lehtonen, Mikko 2014a: Tehtävä kulttuurille? - Lehtonen, Mikko \& Valaskivi, Katja \& Kuusela, Hanna (toim.), Tehtävä kulttuurille. Talouden ja kulttuurin muuttuvat suhteet. Tampere: Vastapaino. 11-38.

Lehtonen, Mikko 2014b: Maa-ilma. Tampere: Vastapaino.

Moisala, Pirkko 2013: Etnomusikologian uudet haasteet. - Moisala, Pirkko \& Seye, Elina (toim.), Musiikki kulttuurina. Helsinki: Suomen Etnomusikologinen seura. 9-25.

P.H. 1970: Perinteenkerääjien jäljissä Ugissa. Miksi nuori maisteri kadotti unenlahjansa? - Uudenkaupungin Sanomat 4.6.1970.

Rastas, Anna 2013: Nimeämisen politiikka ja rasismin rajaamat sosiaaliset suhteet. - Lehtonen, Mikko (toim.), Liikkuva maailma. Liike, rajat ja tieto. Tampere: Vastapaino. 153-175.

Rautiainen, Tarja 1992: Modernismista massakulttuurikeskusteluun: musiikkiradikalismi ja suomalainen taidemusiikki 1955-66. Kansanperinteen, erityisesti kansanmusiikin julkaisematon pro gradu -tutkielma. Tampereen yliopisto: Kansanperinteen laitos.

Rautiainen, Tarja 1997: Avantgarde, pop ja postmoderni suomalaisessa 1960-Iuvun musiikkiradikalismissa. Julkaisematon lisensiaatintutkimus etnomusikologiassa. Tampereen yliopisto: Kansanperinteen laitos.

Rautiainen, Tarja 2001: Pop, protesti, laulu. Korkean ja matalan murroksia 1960Iuvun suomalaisessa populaarimusiikissa. Tampere: Tampere University Press.

Talve, Ilmar 1973: Kansatieteen nykyisestä opetustilanteesta. - Informaatio 3(7)/1973, 1-6.

Tikka, Marko 2013, suullinen tiedonanto Ala-Könnin nauhoista 24.10. 2013.

Urry, John 2002: Mobility and Proximity. - Sociology 36(2): 255-274.

Urry, John 2003: Social Networks, Travel and Talk. - British Journal of Sociology 54(2): 155-175.

Urry, John 2007: Mobilities. Cambridge: Polity Press.

Vesterinen, Arja 1969: Peräseinäjoen entisyys on tutkittu, retkikunta lopettaa työnsä tänään. - Jalasjärven-Peräseinäjoen kunnallissanomat 19.6. 1969.

Waris, Heikki 1961: Suomalaisen yhteiskunnan sosiaalipolitiikka. WSOY: Porvoo Keskustelut

Whelan, Andrew 2014: The Morality of the Social in Critical Accounts of Popular Music. - Sociological Research Online, 19(2): 1-11.

\section{Filosofian tohtori Tarja Rautiainen-Keskustalo toimii musiikintutkimuksen professorina Tampereen yliopistossa.}

